\title{
Introduction to the Special Issue Low Fertility in Comparative Perspective
}

\section{Bali Ram \\ Guest Editor}

This special issue of Canadian Studies in Population is devoted to articles on new trends, patterns and explanations of various dimensions of low fertility. This is not a new venture as over the past two decades, a number of volumes have appeared on diverse issues dealing with low fertility. However, rather than reaching a consensus, scholars have raised new theoretical and methodological questions on why and under what circumstances different populations exhibit different fertility patterns and what can be done to sustain or modify existing fertility levels. The set of papers included in this issue addresses some of these questions.

This issue is an outgrowth of a panel session on parenting and low fertility that I organized at the 2008 annual meeting of the Canadian Population Society, Vancouver, British Columbia. The panelists in this session were: Roderic Beaujot, Alain Belanger, M.V. George, Nathaneal Lauster, and Anatole Romaniuk. These scholars accepted my invitation to develop their presentations into articles for this issue. Several other demographers also accepted my invitation to contribute to this special issue. While most articles in this issue focus on the Canadian scene, some articles deal with the experiences of other countries as well.

Europe and North America have been leaders in demographic changes, which reflect a sharp break from the past. One such change is known as the "demographic transition" that occurred in the $19^{\text {th }}$ and early $20^{\text {th }}$ centuries, depicting declines in mortality and later followed by declines in fertility. Except for certain "aberrations" such as the "baby boom", the secular declines in the two vital rates characterize the demographic history of the West. By 1970, a number of countries had already reached the replacement fertility level of 2.1 births per woman. Reasons for this transition include a broad array of factors such as urbanization, industrialization, modernization, and consequently the increased survival of children, their reduced economic utility, and the direct as well as indirect cost of having many children.

Since the early 1970s, several European countries have been experiencing what some demographers (Lesthaeghe 1995; van de Kaa 1987) call the "second demographic transition" or what Romaniuk (in this issue) terms the "regime of demographic maturity." In 2000-2005, about 70 countries had fertility rates at or below the replacement and many of them had it for two or three decades (United Nations 2007). The rate was as low as 1.5 children per woman for about 35 countries, almost 
all in Europe, while it was 1.3 or lower in certain Southern, Central and Eastern European countries. This "lowest-low fertility," to use Kohler et al.'s (2002; see also Billari 2005) terminology, is one of the most significant features of the second demographic transition.

Canada has closely followed the course of European counties as far as the second demographic transition is concerned. Its fertility level has been below replacement over the past four decades and since the late $1990 \mathrm{~s}$, it has been hovering around 1.5 children per woman. The experience of the province of Quebec is particularly noteworthy, as illustrated by several authors in this issue (see particularly, Beaujot and Wang; Bélanger, Morency and Spielauer, and Charton and LapierreAdamcyk). In the early part of the century, the province had the highest fertility of all regions in Canada, with a fertility rate of about 5.0 children per woman. However, over the past five decades, its total fertility rate fell dramatically and reached its lowest point (1.45 in 2000) by the end of the $20^{\text {th }}$ century.

In recent years, the pace of fertility decline was most striking in the Atlantic Provinces. During the 1970s, the fertility rate in Newfoundland and Labrador used to be among the highest of all regions in Canada. But, since the mid-1990s its fertility rate has been the lowest (around 1.3 children per woman), lower than even Quebec's (Milan and Martel 2008). Interestingly, this happened despite the slow-moving economy of the province.

Canada also exhibits a relatively high incidence of childlessness. Using the General Social Survey, 2001, Charton and Lapierre-Adamcyk show that $15 \%$ of Canadian women aged $40-49$ - born approximately between 1951 and 1961-were childless. However, Belanger, Morency and Spielauer demonstrate that childlessness has continued to increase in recent years. According to their estimates based on microsimulation models, about a quarter of all Canadian women and $27 \%$ of those from Quebec born after 1955 are expected to remain childless.

A higher incidence of common-law living is another important feature of Canada's second demographic transition, once again with Quebec being in the lead (Milan, Vezina and Wells 2007; see also Bélanger, Morency and Spielauer in this volume). In 2006, about 35\% of couples in Quebec lived in a common-law union, higher than that even in Sweden (25\%), Finland (24\%), and Denmark (22\%). Belanger and his colleagues show that in Quebec, about two-fifths of first births took place in a common-law union, as well as about one-third of second and third births. Quebecers are also ahead of people in other parts of the country in terms of contraceptive use as a method of birth control. As the article by Charton and Lapierre-Adamcyk shows, a relatively large proportion 
(about half) of the Quebec couples, even those with just one child, have undergone sterilization.

More recently, some less industrialized countries have joined the low-fertility group, with China, Cuba, Hong Kong, South Korea, Singapore, and Taiwan being in the forefront. In 2000-2005, the total fertility rate was as low as 1.35 for Singapore, 1.23 for South Korea and 0.94 for Hong Kong (United Nations 2007). China's example is unique, in that, despite modest changes in industrialization, modernization and economic development its fertility fell at an extraordinarily rapid pace not previously experienced by any other country over a comparable span of time. As the article by Zhao and Guo shows, China's has experienced an unprecedented fertility decline since the early 1970 s, with its fertility rate falling from about 6 children per woman to approximately 1.45 children over the past four decades. Zhao and Guo assert that a radical family planning campaign launched by the Chinese government in the early 1970s played an important role in the large reduction of China's fertility, although it is possible that the one-child policy that was introduced in 1979 may have accelerated the pace of fertility reduction (Bongaarts and Greenhalgh 1985).

India's Kerala state is another unique example where fertility has declined below the replacement level without significant urbanization, industrialization and economic development. Although the national family planning program did play an important role in fertility reduction in Kerala, the article by George shows that the state possessed a number of ingredients of the classical demographic transition. Compared with other states in India, over the past several decades Kerala has been further ahead in terms of women's education, gender equality, high age at marriage, and low infant mortality.

Another noticeable feature of the demography of low-fertility regions is delayed childbearing. In the industrialized world, the mean age of women at first birth has been rising since the 1970s, with Scandinavia leading the way (Council of Europe 2006; Frejka and Sardon 2006; Pinelli and De Rose 2001). In the 1970s, the mean age at first birth in most industrialized countries was less than 25 years; by 2006, it had reached 30 years or higher in about 16 countries. The first-order births, which are known to be a demographic phenomenon of women in their 20 s, are not uncommon anymore for women in their 30s. According to some estimates, the percentage of births to mothers aged 30 or over exceeds $40 \%$ in several countries (Pinelli and De Rose 2001).

The effect of delayed childbearing on current low fertility is well known (Bongaarts and Feeney 1998; Kohler, Billari and Ortega 2002; Morgan 1991, 1996; Sanchez-Barricarte and Fernandez-Carro, 2007; Sobotka 2004). It is possible-indeed likely—that after delaying 
motherhood for a long period of time, particularly in the late 30 s, some couples may find a child-free lifestyle a desirable and socially acceptable alternative to parenthood, while others may not be able to produce children even if they would like to because of subfecundity or fertility impairment (Gustafsson 2001; Morgan 1996; Nicoletti and Tanturri 2008). It is also possible that some of the delayers stop at one child either because of economic reasons or because they are fully contented with only one child. However, studies show that most couples continue to a second because having only one child is popularly viewed as "undesirable" for the child (Blake 1981; Hoffman and Hoffman 1973).

Some analysts argue that the current low fertility is a temporary phenomenon and sooner or later it will end and fertility will increase once the postponement of childbearing abates (Bongaarts 2002; Bongaarts and Feeney 1998; Morgan 1996; Sobotka 2004). Precisely, this is what has happened recently in some European countries and Canada where significant upturns in fertility were observed. Although reasons for these upturns are not clear, the classical procyclical economic model appears to be the focus of most discussions. It is posited that other things being equal, in good economic times couples will have a larger number of children, just as they will have more cars and more vacations. As illustrated by Trovato and Beaujot and Wang in this issue, in recent years Alberta's fertility has been responding favourably to the overall economic revival and good employment opportunities for young couples. However, in explaining the recent rise in Quebec's fertility, Beaujot and Wang give credit to the highly subsidized and universally accessible child care programs. Their observation on the positive effect of husbands' involvement in childcare on the likelihood of the wives' having a second child is particularly revealing. Interestingly, Mills (this volume) comes to a somewhat different conclusion in her multilevel analysis of the relationship between gender equality and fertility in 24 European countries. Using measures of societal gender equality and micro-level data from the European Social Surveys 2004-05, she found that measures related to economic security had a positive effect on fertility intentions. However, the measure of gender equity that focused on household gender equity and universal caregiver model lowered women's fertility intentions.

Delayed childbearing and low fertility are often thought to be a rational response to economic uncertainty, particularly among young adults (Easterlin 1976; Kohler et al. 2002). Some studies suggest that in Southern, Central and Eastern European countries, steep fertility declines may have occurred because of political upheaval and economic uncertainty. As Lauster's article demonstrates, residential crowding, a reasonable proxy for economic conditions among young couples, has a 
depressing effect on fertility in the United States, Austria, Greece, Portugal and Spain. He argues that residential crowding may explain why fertility in the latter four countries is much lower fertility than in the United States.

However, generally demographers are skeptical that fertility will bounce back to the replacement level and stay there for long, even if the economic climate improves significantly and the trend toward delayed childbearing stops (Bongaarts 2002; Lesthaeghe and Willems 1999; Kohler et al. 2002). There is a general consensus that below replacement fertility is here to stay. This hypothesis is consistent with the observation that desired family size, which usually exceeds actual fertility in a low fertility context, has dropped below replacement (Goldstein et al. 2003; Sobotka 2009), while childlessness has increased in several European countries (Ronsen and Skrede 2008) This perspective is also consistent with the countercyclical fertility model according to which as women continue to enter into the labour force in large numbers and as their wages continue to rise, the demand for a large number of children will decline (Becker 1981; Butz and Ward 1979; Hyatt and Milne 1991). The higher the wages, the larger the loss a woman would expect from having a child. Women, who can earn higher wages in the labour market, will have fewer children because the opportunity cost of their time with children is higher. Since children are intensive users of women's time, the opportunity cost of childbearing and childrearing is expected to rise with increases in women's labour force participation and wages. Thus, as Butz and Ward (1979) hypothesize, "Good times economically are the most expensive time to have children for women who are employed or on the margin of being employed. The larger the proportion of such women in the population, the greater the likelihood that good times will be associated with low fertility for the whole population."

However, research is still ambiguous on how low fertility can be and why couples in industrialized countries continue to have any children at all (Golini 1998; Bongaarts 2002; Morgan 2003; Morgan and King 2001; Schoen et al. 1997). Theoretically, one might argue that the average fertility level could decline to zero in many industrialized countries, given the high direct and indirect costs of having children and their reduced economic utility. Yet, childlessness is not highly prevalent in low fertility countries and there have not been large increases in the proportion of women who intend to remain childless (Morgan 1991; Billari 2005; Kohler et al. 2002). As the article by Edmonston, Lee, and $\mathrm{Wu}$ shows, only $7 \%$ of Canadian married (including common-law) women aged 15 to 44 intend to remain childless, a proportion that has remained unchanged over the study period. Perhaps, there is a "biological or genetic predisposition" or "evolutionary basis imprinted in human 
biology" behind the desire for parenthood (Foster 2000; Morgan 2003; Morgan and King 2001; Pott 1997). Or, as Foster (2000) argues, the "need to nurture... is sufficiently strong to ensure that the majority of women will, other things being equal, want to bear at least one child, despite the substantial costs of doing so." Schoen and colleagues (1997) demonstrated that children were "social resources" and served as "social capital" to parents. Early studies on "value of children" also found children as a source of "psychological satisfaction" (Hoffman and Hoffman 1973). However, these are poorly researched hypotheses. More studies need to be done in order to address the question as to why couples in industrialized countries still want children.

As Edmonston and his colleagues in this issue and a number of researchers (Bongaarts 2001, Morgan 2003; Quesnel-Vallee and Morgan 2003; Sobotka 2009) show, fertility intentions of women in industrialized countries have been relatively stable over time, hovering around two children, while actual fertility has continued to decline substantially below the replacement level. The divergence between actual and intended fertility implies that there are some obstacles that do not allow couples to achieve their intended family size and if those obstacles are removed couples on average will have two children. Needless to say, this is a subject for further research.

One of the major messages of this special volume is that low fertility is here to stay, although it is not clear what the low level will be. There is evidence that lowest-low fertility is a temporary phenomenon and sooner or later it will rebound. Current low fertility in most industrialized countries, including Canada, is largely a product of successive postponement of childbearing. Once further postponement stops, fertility will rise. Some countries are already witnessing this pattern. However, demographers are highly skeptical that fertility will bounce back to the replacement level.

Economic uncertainty, particularly among younger couples, is often suggested as the major factor behind low fertility in the West. Once countries move toward economic recovery and employment opportunities augment, couples may begin childbearing earlier and realize their desired family size. However, the roles of other factors such as the emergence of new life styles (for example, common-law living), higher labour force participation and wages of women, and gender equality on job and at home in explaining fertility change cannot be ignored. According to much of the research these factors exert depressing effects on fertility, although there is some new evidence-particularly that coming from Nordic countries - to the contrary (Billari and Kohler 2004; Feyrer, Sacerdote and Stern 2008; McDonald 2000). It appears that familyfriendly public policies (such as that in Quebec and a number of 
European countries) that enable women to combine their work and childcare responsibilities are at work as far as their positive effect on fertility is concerned. However, it is still too early to come up with a firm conclusion about the long-term influence of family polices on fertility (see Gauthier and Philipov 2008). Obviously, further research is required on this subject.

\section{References}

Becker, G. 1981. A Treaties on the Family. Cambridge: Harvard University Press.

Billari, F. C. and H.-P. Kohler. 2004. Patterns of low and lowest low fertility in Europe. Population Studies 58: 11-17.

Billari, F. C. 2005. Europe and its fertility: From low to lowest- low. National Institute Economic Review 194: 56-73.

Blake, J. 1981. The only child in America: Prejudice versus performance. Population and Development Review 7: 43-57.

Bongaarts, J. 2001. Fertility and reproductive preferences in posttransitional societies. Population and Development Review 27 (Supplement): 261-281.

Bongaarts, J. 2002. The end of the fertility transition in the developed world. Population and Development Review 28: 419-443.

Bongaarts, J. and S. Greenhalgh. 1985. An alternative to the one-child policy in China. Population and Development Review 11: 585617.

Bongaarts, J. and G. Feeney. 1998. On the quantum and tempo of fertility. Population and Development Review 24: 271-291.

Butz, W. P. and M. P. Ward. 1979. The emergence of countercyclical U.S. fertility. The American Economic Review 69: 318-328.

Council of Europe. 2006. Recent Demographic Developments in Europe 2005. Strasbourg: Council of Europe Publishing. 
Easterlin, R. A. 1976. The conflict between aspirations and resources. Population and Development Review 2: 417-425.

Feyrer, J., B. Sacerdote and A. D. Stern. 2008. Will the stork return to Europe and Japan? Understanding fertility within developed nations. Journal of Economic Perspectives 22: 3-22.

Foster, C. 2000. The limits to low fertility: A biosocial approach. Population and Development Review 26: 209-234.

Frejka, T. and J.-P. Sardon. 2006. First birth trends in developed countries: Persisting parenthood postponement. Demographic Research (Max-Planck-Gesellschaft) 15:147-180.

Gauthier, A. H. and D. Philipov (eds.). 2008. Special issue on Can policies enhance fertility in Europe? Vienna Yearbook of Population Research 2008: 1-16.

Goldstein, J. R., W. Lutz and M. R. Testa. 2003. The emergence of subreplacement family size ideals in Europe. Population Research and Policy Review 22: 479-496.

Golini, A. 1998. How low can fertility be? Empirical exploration. Population and Development Review 24: 59-73.

Gustafsson, S. S. 2001. Optimal age at motherhood: Theoretical and empirical considerations on postponement of maternity in Europe. Journal of Population Economics 14: 225-247.

Hagewen, K. J. and S. P. Morgan. 2005. Intended and ideal family size in the United States, 1970-2002. Population and Development Review 31: 507-527.

Hoffman, L. W. and M.L. Hoffman. 1973. The value of children to parents, in Psychological Perspectives on Population, edited by James T. Fawcett. New York: Basic Books, pp.19-76.

Hyatt, D. E. and W. J. Milne. 1991. Countercyclical fertility in Canada: Some empirical results. Canadian Studies in Population18: 1-15.

Kohler, H.-P., F. C. Billari and J. A. Ortega. 2002. The emergence of lowest-low fertility in Europe during the 1990s. Population Development Review 28: 41-80. 
Kohler, H.-P., J. L. Rodgers and K. Christensen. 1999. Is fertility behavior in our genes: Findings from a Danish twin study. Population Development Review 25: 253-288.

Lesthaeghe, R. 1995. The second demographic transition: An interpretation, in Gender and Family Change in Industrial Countries, edited by K. Mason and A. Jensen. Oxford: Clarendon Press, pp. 17-62.

Lesthaeghe, R. and P. Willems. 1999. Is low fertility a temporary phenomenon in the European Union? Population and Development Review 25: 211-228.

McDonald, P. 2000. Gender equity, social institutions and the future of fertility. Journal of Population Research 17: 1-16.

Milan, A., M. Vezina and C. Wells. 2007. Family Portrait: Continuity and Change in Canadian Families and Households in 2006, 2006 Census. Catalogue No. 97-553-XIE. Ottawa: Statistics Canada.

Milan, A. and L. Martel. 2008. Report on Current Demographic Situation in Canada, 2005 and 2006. Catalogue No. 91-209-X. Ottawa: Statistics Canada.

Morgan, S. P. 2003. Is low fertility a twenty-first-century demographic crisis? Demography 40: 589-604.

Morgan, S. P. 1991. Late nineteenth- and early twentieth-century Childlessness. American Journal of Sociology 97: 779-807.

Morgan, S. P. 1996. Characteristic features of modern fertility. Population and Development Review 22(S): 19-63.

Morgan, S. P. and R. B. King. 2001. Why have children in the $21^{\text {st }}$ century? Biological predisposition, social coercion, rational choice. European Journal of Population 17: 3-20.

Nicoletti, C. and M. L. Tanturri. 2008. Differences in delaying motherhood across European countries: Empirical evidence from the ECHP. European Journal of Population 24: 157-183. 
Pinelli, A. and A. De Rose. 2001. Delayed Fertility in Europe: Determinants and Consequences. Paper presented at EAPS Population Conference 2001. Helsinki, Finland.

Potts, M. 1997. Sex and the birth rate: human biology, demographic change and access to fertility-regulation methods. Population and Development Review 23: 1-39.

Quesnel-Vallee, A. and S. P. Morgan. 2003. Missing the target? Correspondence of fertility intentions and behavior in the U.S. Population Research and Policy Review 22: 497-525.

Ronsen, M. and K. Skrede. 2008. Fertility trends and differentials in the Nordic countries-Footprints of welfare policies and challenges on the road ahead. Vienna Yearbook of Population Research 2008: 103-123.

Sobotka, T. 2004. Is lowest-low fertility in Europe explained by the postponement of childbearing? Population and Development Review 30: 195-220.

Sobotka, T. 2009. Sub-replacement fertility intentions in Austria. European Studies in Population 25: 387-412.

Schoen, R., Y. J. Kim, C. A. Nathanson, J. Fields and N. M. Astone. 1997. Why do Americans want children? Population and Development Review 23: 333-358.

Sanchez-Barricarte, J. J. and R. Fernandez-Carro. 2007. Patterns in the delay and recovery of fertility in Europe. European Journal of Population 23: 145-170.

United Nations. 2007. World Population Prospects: The 2006 Revision, Vol. I. Department of Economic and Social Affairs, Population Division, United Nations.

Van de Kaa, D. J. 1987. Europe's Second Demographic Transition. Population Bulletin (Population Reference Bureau) 42: 1-57. 